\title{
Article \\ Anticancer Activity of Urease Mimetic Cobalt (III) Complexes on A549-Lung Cancer Cells: Targeting the Acidic Microenvironment
}

\author{
Bhawna Uprety ${ }^{1, *(\mathbb{D})}$, Rahul Chandran ${ }^{1, *(\mathbb{C})}$, Charmaine Arderne ${ }^{2}(\mathbb{C})$ and Heidi Abrahamse ${ }^{1(\mathbb{C}}$ \\ 1 Laser Research Centre, Faculty of Health Sciences, University of Johannesburg, P.O. Box 17011, \\ Johannesburg 2028, South Africa; habrahamse@uj.ac.za \\ 2 Research Centre for Synthesis and Catalysis, Department of Chemical Sciences, University of Johannesburg, \\ P.O. Box 524, Johannesburg 2092, South Africa; carderne@uj.ac.za \\ * Correspondence: buprety@uj.ac.za (B.U.); rahulc@uj.ac.za (R.C.); Tel.: +27-11-559-6926 (R.C.)
}

check for

updates

Citation: Uprety, B.; Chandran, R.;

Arderne, C.; Abrahamse, H.

Anticancer Activity of Urease Mimetic

Cobalt (III) Complexes on A549-Lung

Cancer Cells: Targeting the Acidic

Microenvironment. Pharmaceutics

2022, 14, 211. https://doi.org/

10.3390/pharmaceutics14010211

Academic Editors: Wukun Liu,

Damiano Cirri and Haibing Zhou

Received: 12 November 2021

Accepted: 11 January 2022

Published: 17 January 2022

Publisher's Note: MDPI stays neutral with regard to jurisdictional claims in published maps and institutional affiliations.

Copyright: (c) 2022 by the authors. Licensee MDPI, Basel, Switzerland. This article is an open access article distributed under the terms and conditions of the Creative Commons Attribution (CC BY) license (https:// creativecommons.org/licenses/by/ $4.0 /)$.

\begin{abstract}
Tumour cells maintain a local hypoxic and acidic microenvironment which plays a crucial role in cancer progression and drug resistance. Urease is a metallohydrolases that catalyses the hydrolysis of urea into ammonia and carbon dioxide, causing an abrupt increase of $\mathrm{pH}$. This enzymatic activity can be employed to target the acidic tumour microenvironment. In this study, we present the anticancer activities of urease mimetic cobalt (III) complexes on A549 cells. The cells were treated with different doses of cobalt (III) complexes to observe the cytotoxicity. The change in cellular morphology was observed using an inverted microscope. The cell death induced by these complexes was analysed through ATP proliferation, LDH release and caspase 3/7 activity. The effect of extracellular alkalinization by the cobalt (III) complexes on the efficacy of the weakly basic drug, doxorubicin (dox) was also evaluated. This combination therapy of dox with cobalt (III) complexes resulted in enhanced apoptosis in A549 cells, as evidenced by elevated caspase 3/7 activity in treated groups. The study confirms the urease mimicking anticancer activity of cobalt (III) complexes by neutralizing the tumour microenvironment. This study will motivate the applications of transition metal-based enzyme mimics in targeting the tumour microenvironment for effective anticancer treatments.
\end{abstract}

Keywords: urease mimetic activity; tumour microenvironment; cobalt (III) complexes

\section{Introduction}

The last few decades have seen an upsurge in cancer research. Many developments and milestones have been achieved in discovering compounds with effective anticancer therapeutic properties. Although a lot of such potent drugs such as doxorubicin and cisplatin were discovered several years ago and are still used clinically to treat different kinds of cancers; they are often limited by severe side effects on healthy cells $[1,2]$. Recently, the research focus has shifted to develop target specific treatments. These involve the design of target specific drug delivery agents such as using nanotechnology [3-6], immunotherapy [7,8], and more recently, antibody conjugation [9-11] to allow delivery of the drug molecule directly at the tumour site. These procedures are believed to improve drug efficacy while minimizing adverse side effects [12]. Although considerable advancements have been achieved, most of these treatments often require chronic therapy and offer only moderate effects. Therefore, new treatment methods are in demand to fight this deadly disease.

Recently, some researchers have focused on targeting the microenvironment surrounding tumour cells [13-17]. Hypoxia plays a crucial role in suppressing the body's immune response and proliferation of tumour cells, which tend to become heterogeneous at anatomic, genomic, and metabolic levels. This may be due to the deficiency of essential nutrients and oxygen around cancer cells [18]. Another implication of the hypoxic microenvironment is the increased generation of non-oxidized acids such as lactic acid in the 
tumour extracellular environment [19]. Consequently, the $\mathrm{pH}$ around tumour cells could be lowered to up to $6.2[19,20]$. The acidosis of the tumour extracellular environment has multi-fold effects on tumour progression; it suppresses the body's immune response and stimulates tumour growth factors, and also interferes with the action of drug molecules by altering the formal charge on the molecule, thereby shifting the partition coefficient between the intracellular and the extracellular regions. This results in greater localization of weakly basic drugs in the extracellular region, thus decreasing the drug efficacy. Tumour cells that have adapted to a low extracellular $\mathrm{pH}$ also exhibit greater expression of $\mathrm{p}$-glycoproteins, which ultimately results in drug resistance [21]. Therefore, current research is now focused on the alkalinization of the extracellular microenvironment to promote the efficacy of existing treatments. Some of the most promising results were obtained by Chao et al. using the urease enzyme [22].

Urease (urea amidohydrolase; E.C.3.5.1.5) is widespread in nature and is present in various forms in several bacteria, fungi, and algae [23]. It is commonly associated with the pathogenesis of various pathogens such as Helicobacter pylori and Mycobacterium tuberculosis. These bacteria survive the acidic conditions of the gut by virtue of their intrinsic urease activity to neutralize the acidity [24]. Likewise, urease activity is also responsible for the ineffective use of nitrogen fertilizers. Urease rapidly hydrolyses urea into ammonia, most of which is dissipated into the environment, rather than being absorbed by the plants [24]. Therefore, much research has been dedicated to inhibiting the enzyme activity to attain the desired therapeutic as well as agricultural benefits [23,25-32]; however, the last decade has seen potential urease mimicking applications [33-36]. The most promising results have been documented for the anticancer applications of the urease enzyme. Chao et al. have developed a series of urease conjugates (DOS47) to induce alkalinization of the interstitial medium surrounding the tumour cells by promoting the hydrolysis of urea to generate ammonia; they also reported a substantial improvement in the anticancer effect of weak base anticancer drugs (doxorubicin and vinblastine) when used synergistically with the urease enzyme [22,37-39]. However, the greatest challenge working with actual enzymes pertains to isolation and storage of the enzyme from different sources, making it a tedious and non-economic process. Moreover, since the enzymes are proteins and can be easily denatured by small changes in temperature and pressure, they provide a very narrow window to explore the desired results.

\section{Materials and Methods}

\subsection{Materials-Physical Measurements}

All chemicals were used as received without further purification and were of the analytical grade. $\mathrm{CoCl}_{2} \cdot 6 \mathrm{H}_{2} \mathrm{O}$ (Sigma-Aldrich, Johannesburg, South Africa), tris(2-aminoethyl)amine (Sigma-Aldrich, Johannesburg, South Africa), triethylaminetetramine (Sigma-Aldrich, Johannesburg, South Africa), and urea (Saarchem, Johannesburg, South Africa) were used as obtained. The complexes were prepared following literature methods [33] using the respective ligands. FT-IR spectra were recorded in Attenuated total reflection mode on a Spectrum BX, Perkin-Elmer FT-IR spectrometer (Perkin-Elmer, Waltham, MA, USA). Electronic spectra of complexes were recorded in water on a Shimadzu $1800 \mathrm{UV}-$ Vis spectrophotometer (Shimadzu, Kyoto, Japan). ${ }^{1} \mathrm{H}$ NMR and ${ }^{13} \mathrm{C}$ NMR spectra were recorded in $\mathrm{D}_{2} \mathrm{O} / \mathrm{CH}_{3} \mathrm{OD}$ on a Bruker Ultrashield 400 Nuclear Magnetic Resonance Spectrometer (Bruker, Billerica, MA, USA). SC-XRD data were obtained on a Bruker Apex-II Duo CCD diffractometer (Bruker). The spectroscopic characterization data for the complexes has been included in the supplementary information.

\subsection{Cell Culture and Treatment}

Commercially purchased lung cancer (A549-ATCC CCL-185), MCF7 breast cancer cell line (ATCC HTB-22), Oesophageal cancer (HKESC-1, Cellonex-SepSci, Johannesburg, South Africa) and fibroblast (WS1-ATCC: CRL-1502' to ATCC ${ }^{\circledR}$ CRL-1502 ${ }^{\mathrm{TM}}$ ) cell lines were used for the cytotoxicity study. Here, MCF-7 and HKESC-1 were used as additional cell lines to determine the toxic response of cobalt (III) complexes. Approximately, $3 \times 10^{5}$ cells 
were seeded in $3.4 \mathrm{~cm}$ diameter culture dishes. A549 cells were cultured in Roswell Park Memorial Institute 1640 Medium (RPMI, Sigma-Aldrich, R8758, Johannesburg, SA, South Africa) supplemented with $10 \%$ foetal bovine serum (FBS, Gibco, 306.00301), 1\% antibacterial (Penicillin-streptomycin-Sigma-Aldrich, Johannesburg, SA, South Africa) and 1\% antifungal (amphotericin-B, Gibco, Thermofisher, 104813, Johannesburg, SA, South Africa) agents; however, MCF-7 and HKESC-1 cells were cultured in Dulbecco's modified Eagle's media (DMEM, Sigma-Aldrich, D 6429) with supplements and antibiotics, as mentioned above. WS1 cells were cultured in Minimum Essential Media (MEM-Sigma-Aldrich, Johannesburg, SA, South Africa) with 1\% Amphotericin-B (Sigma-Aldrich, Johannesburg, South Africa), 1\% penicillin-streptomycin (Sigma-Aldrich, P4333, Johannesburg, South Africa), $0.1 \mathrm{mM}$ Non-essential amino acid (Sigma-Aldrich, M7145, Johannesburg, South Africa), $1 \mathrm{mM}$ sodium pyruvate (Sigma-Aldrich, S8636, Johannesburg, South Africa), $2 \mathrm{mM}$ L-glutamine (Sigma-Aldrich, G7513, Johannesburg, South Africa), and 10\% foetal bovine serum (Gibco, 306.00301). The cultures were maintained at $37^{\circ} \mathrm{C}$ with $5 \% \mathrm{CO}_{2}$ and $85 \%$ humidity for $4 \mathrm{~h}$ to allow the cells to attach. Culture dishes with more than $90 \%$ confluence were used for these experiments. The experimental groups were divided into untreated controls and cells treated with the drugs at three different doses $(8 \mu \mathrm{M}, 16 \mu \mathrm{M}$, and $32 \mu \mathrm{M})$.

\subsection{Stability of Co (III) Complexes}

Since the study is focused on the toxicity of the complexes against lung cancer cells, the stability of the compounds in the A549 cell culture medium was analysed by UV/Vis spectroscopy as well as by SC-XRD analyses. A solution of all the complexes was made ( $\sim 7 \mathrm{mM}, 1 \mathrm{~mL}$ ) by dissolving the compounds in a solution of RPMI supplemented with $10 \%$ foetal bovine serum, $1 \%$ penicillin-streptomycin and $1 \%$ amphotericin-B. The resulting solutions were maintained at $37^{\circ} \mathrm{C}$, and their UV/Vis spectra were analysed for 3 days, every $12 \mathrm{~h}$.

\subsection{Urease Activity}

The urease mimetic activity of the chloro complexes, ([Co(trien) $\left.\mathrm{Cl}_{2}\right] \mathrm{Cl}$ (III) and $\left[\mathrm{Co}(\right.$ tren $\left.\left.) \mathrm{Cl}_{2}\right] \mathrm{Cl}(\mathbf{I V})\right)$ was measured from the culture media of the treated and untreated groups. $100 \mu \mathrm{L}$ of the culture media was withdrawn from treated and untreated groups at fixed time intervals and the urease mimetic activity was measured using the urease activity kit from Merck Sigma-Aldrich, MAK120, following the protocol provided.

\subsection{Cellular Morphology-Inverted Microscopy}

The morphology of the complexes $(8 \mu \mathrm{M}, 16 \mu \mathrm{M}$, and $32 \mu \mathrm{M})$ treated cells was analysed after $24 \mathrm{~h}$ of incubation using an inverted light microscope (Wirsam, Olympus CKX41, Johannesburg, South Africa). After the digital images were recorded, cells were detached using $1 \mathrm{~mL}$ / plate of TrypLE Express (Invitrogen, 12605-028), centrifuged at $3000 \mathrm{rpm}$ for 5 min and re-suspended in Hank's Balanced Salt Solution (HBSS) to perform further assays.

\subsection{Cellular Proliferation-Adenosine Triphosphate (ATP) Luminescent Assay}

The CellTiter-Glo ${ }^{\circledR}$ 3D Cell luminescent assay (Promega, G7571, Anatech Analytical Technology, Bellville, South Africa) is a homogeneous method for the determination of cellular proliferation and quantification of ATP present in metabolically active cells. An equal volume $(50 \mu \mathrm{L})$ of reconstituted ATP reagent and the cell suspension was mixed on a shaker for $2 \mathrm{~min}$ to induce cell lysis, followed by incubation at room temperature for $10 \mathrm{~min}$ in the dark to stabilize the luminescent signal. The luminescent signal was read using the 1420 multilabel counter victor3 (Perkin-Elmer, Separation Scientific, Johannesburg, South Africa).

\subsection{Cytotoxicity-Lactate Dehydrogenase (LDH) Assay}

The membrane integrity was assessed by estimating the amount of LDH present in the culture media. The cytosolic enzyme LDH will be released into the media due to membrane 
damage. The Cyto-Tox96 X assay (Anatech, Promega G 400) was used to measure the LDH released. An equal volume $(50 \mu \mathrm{L})$ of reconstituted $\mathrm{LDH}$ reagent and cell culture medium was mixed and incubated in the dark at room temperature for $30 \mathrm{~min}$. The colourimetric mixture was measured spectrophotometrically at $490 \mathrm{~nm}$ (Perkin-Elmer, VICTOR3 ${ }^{\mathrm{TM}}$ ).

\subsection{Caspase $3 / 7$ Activity}

A549 cells cultured in $3.4 \mathrm{~cm}$ diameter plates were incubated with cobalt complexes (III and IV) under standard culture conditions. After $24 \mathrm{~h}$ of treatment, cultured media from each group were transferred to white-walled luminescent plates. Cells from each plate were detached using TrypLE Express (Invitrogen, 12605-028, Johannesburg, South Africa), centrifuged and re-suspended in culture media. An equal volume of cell suspension was then transferred to their respective wells. $100 \mu \mathrm{L}$ of Caspase-Glo ${ }^{\circledR} 3 / 7$ Reagent was added to each well, mixed and incubated in dark for $1 \mathrm{~h}$. The luminescence produced in each well was read using the 1420 multilabel counter victor3 (Perkin-Elmer, Separation Scientific).

\subsection{Statistical Analysis}

All the results were expressed as mean \pm SEM. Statistical significance was determined using one way ANOVA followed by Dunnett's multiple comparison tests. $p<0.05$ was considered statistically significant.

\section{Results}

We have recently reported the urease-like activity of cobalt (III) complexes using urea as the ideal substrate [33]. In the present study, we have explored the preliminary anticancer activities of these urease mimetic cobalt (III) complexes towards lung cancer and breast cancer cell lines. Transition metal-based enzyme mimics are significant agents for several catalytic and therapeutic applications. They offer several advantages over the conventional enzymes, such as long shelf life, undemanding storage conditions and a wide window of activity, whilst maintaining the desired enzymatic activity. Thus, suitably designed transition metal complexes with biocompatible ligands as enzyme mimics can pave the way for a new era of therapeutic agents.

\subsection{Synthesis, Characterization, Stability and Urease Mimetic Activity of the Complexes}

Urease activity is usually considered unfavourable for agricultural, industrial, and pharmaceutical applications [40-42]. Medicinally, urea is a common physiological metabolite and serves as an ideal substrate for pathogen growth. Therefore, urease inhibition has long been used as a convenient tool to target several pathogens in the human body $[24,28,30,43]$. However, lately, the notorious urease activity has been successfully employed in anticancer treatment. The alkalinity resulting from the urease catalysed hydrolysis of urea has been shown to be effective in treating cancer cells $[14,19,44]$. In the present study, we have reported the urease-like anticancer activity of urease mimetic cobalt (III) complexes (Figure 1) against lung cancer cells (A549), breast cancer cells (MCF7), and oesophageal cancer cells (HKESC-1). All the complexes were prepared in excellent yields following reported methods and characterized by various spectroscopic techniques $[33,45,46]$.

The stability of the compounds in the cell culture medium was analysed by UV/Vis spectroscopy as well as by SC-XRD analyses. A solution of all the complexes was made ( 7 mM, $1 \mathrm{~mL}$ ) by dissolving the compounds in a solution of RPMI supplemented with $10 \%$ foetal bovine serum, $1 \%$ penicillin-streptomycin and $1 \%$ amphotericin-B. The resulting solutions were maintained at $37^{\circ} \mathrm{C}$, and their UV/Vis spectra were analysed for 3 days, every $12 \mathrm{~h}$. There was no appreciable change in the spectra for the complexes over 3 days, indicating the stability of the complexes in solution (Figure S1). Furthermore, efforts were made to re-crystallise the compounds from a solution of the cell culture media by means of the slow evaporation method. Diffraction quality single crystals were obtained from the solutions of $\left[\mathrm{Co}\right.$ (tren) $\left.\left(\mathrm{NO}_{2}\right)_{2}\right] \mathrm{Cl}$ (II) and [Co(trien) $\left.\mathrm{Cl}_{2}\right] \mathrm{Cl}$ (III). The crystals were analysed by SC-XRD analyses and were found to be structurally similar to the initial compounds. The 
crystal structures are presented in Figures S2 and S3. Interestingly, while [Co(trien) $\left.\mathrm{Cl}_{2}\right] \mathrm{Cl}$ was similar to the starting material, the $\left[\mathrm{Co}(\right.$ tren $\left.)\left(\mathrm{NO}_{2}\right)_{2}\right] \mathrm{Cl}$ crystallised as a polymorph in a different space group. The most prevalent polymorph for this compound exists in orthorhombic space group $(\mathrm{Pbca})$, and the only reported monoclinic form $(\mathrm{A} 2)$ was isolated serendipitously [47]; however, the change from the orthorhombic to monoclinic could imply that the latter is the therapeutically active polymorph, and hence gets stabilised in the cell culture medium. Such preference for selective conformations is quite evident in biological systems $[48,49]$. Nevertheless, the crystals obtained after recrystallization were found to be structurally similar to the starting ones, further substantiating the stability of the compounds in the cell culture media.

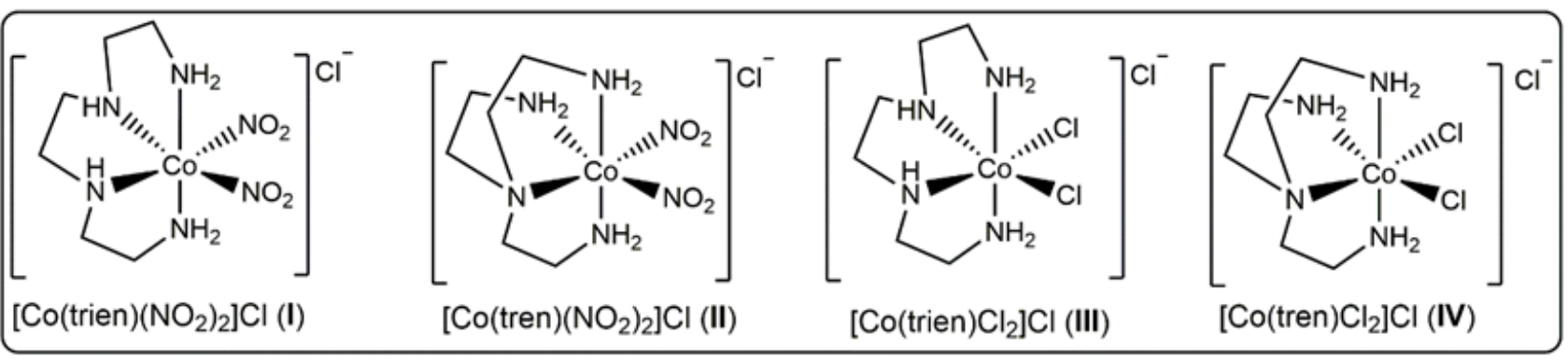

Figure 1. Structures of the complexes under study.

The urease-like activity of some of the complexes was explored using urea as an ideal substrate, and the results were presented in recent publications [33,50]. The increase in the basicity of the solution is believed to result from catalytic cleavage of urea during the reaction. A detailed in vitro catalytic study on $\left[\mathrm{Co}\right.$ (tren) $\left.\mathrm{Cl}_{2}\right] \mathrm{Cl}(\mathbf{I V})$ induced cleavage of urea into ammonia was reported by some of us recently. The increasing alkalinity was monitored spectrophotometrically with the aid of a $\mathrm{pH}$ dependent indicator, phenolphthalein [33].

The ammonia generated because of urease mimetic activity in treatment groups was ascertained by $\mathrm{pH}$ measurements of the cell culture media after $24 \mathrm{~h}$ of treatment of A549 cells with the cobalt (III) complexes. Interestingly, the culture media from the cells treated with $\left[\mathrm{Co}\right.$ (tren) $\left.\mathrm{Cl}_{2}\right] \mathrm{Cl}(\mathbf{I V})$ and $\left[\mathrm{Co}\right.$ (trien) $\left.\mathrm{Cl}_{2}\right] \mathrm{Cl}$ (III) were found to be slightly basic as compared to the other groups. This prompted us to measure the urease mimetic activity of the chloro complexes under treatment conditions. Therefore, confluent cells in culture dishes were treated with the optimised dose of the cobalt (III) complexes $(32 \mu \mathrm{M})$ in the presence of urea $(2 \mathrm{mM})$. The results were compared to cells treated with urea alone $(2 \mathrm{mM})$ (untreated group) to negate any background absorbance that may arise due to the culture medium or urea. A total of $100 \mu \mathrm{L}$ of the culture medium was withdrawn at fixed time intervals, and the urease mimetic activity was measured using the urease activity kit from Sigma Aldrich as per the protocol available with the test kit. The increase in absorbance at $670 \mathrm{~nm}$ at fixed time intervals for the cobalt treated groups was compared to the untreated group. The results are presented in Figure 2. The A549 cells treated with $\left[\mathrm{Co}(\right.$ tren $\left.) \mathrm{Cl}_{2}\right] \mathrm{Cl}$ (IV) and [Co(trien) $\left.\mathrm{Cl}_{2}\right] \mathrm{Cl}$ (III) depicted a gradual increase in absorbance at $670 \mathrm{~nm}$, and after $24 \mathrm{~h}$ of treatment, the absorbance, and hence the urease mimetic activity for $\left[\mathrm{Co}(\operatorname{tren}) \mathrm{Cl}_{2}\right] \mathrm{Cl}$ (IV) was significantly higher than $\left[\mathrm{Co}\right.$ (trien) $\left.\mathrm{Cl}_{2}\right] \mathrm{Cl}$ (III). Similar trends have been reported for catalytic studies as well $[33,50]$. There was no appreciable change observed in the culture medium of untreated cells, thereby substantiating the urease mimetic generation of ammonia by the cobalt (III) complexes. The urease activity results are also reflected in the anticancer activities, with $\left[\mathrm{Co}(\right.$ tren $\left.) \mathrm{Cl}_{2}\right] \mathrm{Cl}(\mathbf{I V})$ performing better than $\left[\mathrm{Co}(\right.$ trien $\left.) \mathrm{Cl}_{2}\right] \mathrm{Cl}$ (III) for A549 cells. 


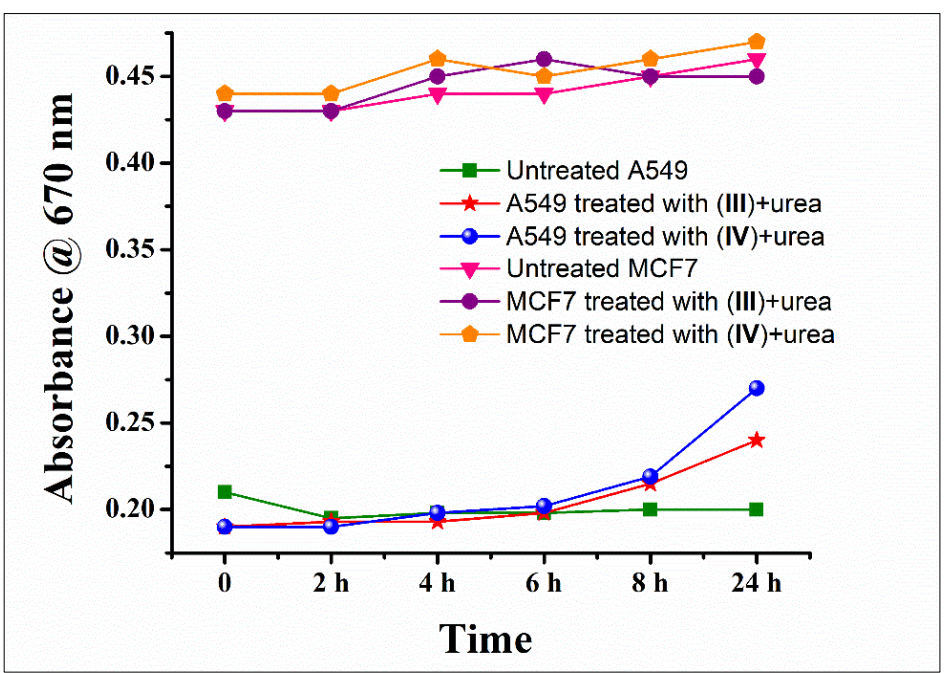

Figure 2. Urease mimetic activity of $\left[\mathrm{Co}\right.$ (trien) $\left.\mathrm{Cl}_{2}\right] \mathrm{Cl}$ (III) and $\left[\mathrm{Co}\right.$ (tren) $\left.\mathrm{Cl}_{2}\right] \mathrm{Cl}$ (IV) measured extracellularly in the cell culture medium. The absorbance at $670 \mathrm{~nm}$ corresponds to the ammonia concentration generated in response to the catalytic urease activity.

The urease activity results of the cobalt (III) complexes for MCF7 cells were completely surprising and conflicting. There was no appreciable change in absorbance at $670 \mathrm{~nm}$ for the cells treated with $\left[\mathrm{Co}(\right.$ tren $\left.) \mathrm{Cl}_{2}\right] \mathrm{Cl}(\mathbf{I V})$ and $\left[\mathrm{Co}\right.$ (trien) $\left.\mathrm{Cl}_{2}\right] \mathrm{Cl}$ (III) over $24 \mathrm{~h}$ (Figure 2). The absorbances for the treated groups and the untreated group were almost the same, indicating no measurable urease activity in this case. Predictably, the complexes demonstrated poor anticancer activities as well towards MCF7 cells; however, the activity of the complexes against HKESC-1 cells was comparable to that observed in A549, negating the role of cell culture media in the observed therapeutic activity. Nevertheless, it is to be noted that urease induced alkalization and anticancer activity has been reported in both A549 and MCF7 cells [12,18].

\subsection{Cytotoxicity-Lactate Dehydrogenase (LDH) Assay}

The WS1 cells in the control and treated groups were seen to be healthy with no significant difference observed in growth and proliferation (Figure S4). The LDH content quantified from these groups did not show a significant difference indicating the safety of the standardized doses. In contrast, the membrane integrity of A549 cells after the treatment with the cobalt complexes depicted significant damage and release of LDH into the culture media. It was interesting to note that the degree of membrane damage in cells treated with different Cobalt complexes varied in accordance with the urease mimetic activity of the complexes. Here, $\left[\mathrm{Co}\right.$ (trien) $\left.\mathrm{Cl}_{2}\right] \mathrm{Cl}$ (III) and $\left[\mathrm{Co}(\right.$ tren $\left.) \mathrm{Cl}_{2}\right] \mathrm{Cl}$ (IV) complexes outperformed other Co complexes (Figure 3A). The $\left[\mathrm{Co}(\right.$ tren $\left.)\left(\mathrm{NO}_{2}\right)_{2}\right] \mathrm{Cl}(\mathrm{II})$ and $\left[\mathrm{Co}(\right.$ trien $\left.)\left(\mathrm{NO}_{2}\right)_{2}\right] \mathrm{Cl}(\mathrm{I})$ complexes exhibit poor catalytic urease activity as well, owing to the strong affinity and poor lability of the nitro group towards cobalt [33].

Based on these preliminary results, further experiments were performed using the two chloro substituted complexes, [ $\mathrm{Co}($ trien $\left.) \mathrm{Cl}_{2}\right] \mathrm{Cl}$ (III) and $\left[\mathrm{Co}\right.$ (tren) $\left.\mathrm{Cl}_{2}\right] \mathrm{Cl}(\mathbf{I V})$, while the nitro complexes were dropped out. To ascertain the urease-like anticancer activity of the cobalt complexes, the cells were treated with the complexes alone and with the addition of urea. The resulting alkalinity of urease activity has been shown to enhance the activity of weakly basic anticancer drugs, such as doxorubicin. Such drugs-enzyme combinations and conjugates are gaining increasing attention in recent times $[19,36]$. Therefore, we also studied the combined effects of the cobalt complexes and doxorubicin against A549 cells. The $\mathrm{IC}_{50}$ dose for doxorubicin was used for all the experiments. There was a significant dose dependent LDH release with increasing concentrations of the cobalt complexes and their standardized dose combinations. Interestingly, the activity of the cobalt complexes improved on the addition of urea compared to the complexes alone. When the complex- 
urea combination was used with doxorubicin, the activity increased by several folds compared to the cobalt complexes alone or with urea (Figure 3B). Moreover, the combination groups also surpassed the toxicity induced by the positive control drug, doxorubicin (Figure 3B) alone. This substantiates our hypothesis that the cobalt complexes mediate the hydrolysis of urea in the culture medium, thereby increasing the $\mathrm{pH}$ and altering the tumour microenvironment. The increased basicity also improves the diffusion and the activity of doxorubicin against cancer cells. The results show the following trend; complex alone $<$ complex + urea $<$ doxorubicin $<$ complex + doxorubicin $<$ complex + urea + doxorubicin. There was no appreciable effect when MCF7 were treated with the dose optimised for A549 (Figure S5). However, complexes (III and IV) were found to be toxic to HKESC-1 cells (Figure S6).
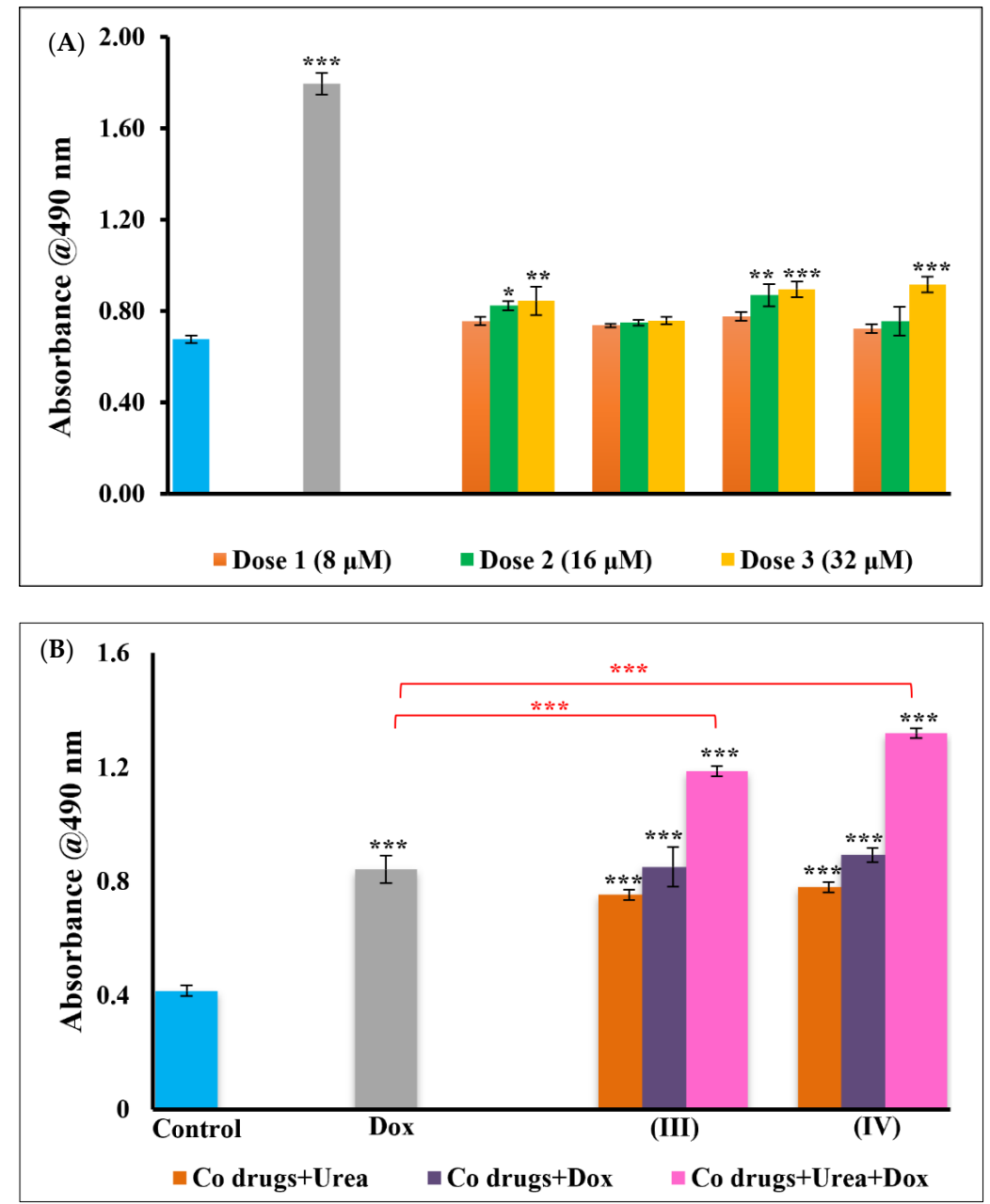

Figure 3. LDH levels of A549 cells. (A) The control cells (untreated) and cells treated with different concentrations $(8 \mu \mathrm{M}, 16 \mu \mathrm{M}$, and $32 \mu \mathrm{M})$ of the cobalt (III) complexes and doxorubicin (50 $\mathrm{nM}$ ) showed different levels of LDH release. (B) Significant LDH release was observed when the optimized dose of the cobalt complexes $(32 \mu \mathrm{M})$ was combined with urea $(2 \mathrm{mM})$ and doxorubicin $(50 \mathrm{nM})$ in treated groups. The action of doxorubicin was fairly increased when the complexes (III and IV) were combined with urea. Loss of membrane integrity and LDH release can be directly related to $\mathrm{pH}$ increase and facilitating Doxorubicin into cells. The data represent the mean $\pm \mathrm{SEM}$. Results are significantly different at ${ }^{*} p<0.05,{ }^{* *} p<0.01$ and ${ }^{* * *} p<0.001$ when compared to control and doxorubicin.

\subsection{Adenosine Triphosphate (ATP) Cell Metabolism Assay}

A similar trend was observed with ATP of WS1 and A549 cells. No significant ATP proliferation was observed in WS1 cells depicting the safety of complexes against normal cells 
(Figure S7); however, toxicity induced by cobalt complexes in A549 was clearly observed in treatment groups. The dose dependent ability of the cobalt complex and their combinations in disrupting cellular membrane and release of LDH was equally observed in the ATP metabolism of cells. There was an increase in cellular metabolism, as demonstrated by the increased levels of ATP in A549 control cells. Exposure of A549 cells to the cobalt (III) complexes reduced the intracellular ATP pool. The rate of cellular proliferation and ATP levels were also altered after the treatment compared to control cells. The drugs $\left(\left[\mathrm{Co}(\operatorname{trien}) \mathrm{Cl}_{2}\right] \mathrm{Cl}\right.$ (III) and $\left[\mathrm{Co}\right.$ (tren) $\left.\mathrm{Cl}_{2}\right] \mathrm{Cl}$ (IV))-urea combination as well as the combinations with doxorubicin, induced profuse toxicity in cells and reduction of ATP. These findings further support our claim that urease mimetic activity of the cobalt complexes induces anticancer effects by facilitating doxorubicin action, as observed in the LDH assay. The results are presented in Figure 4. As observed with LDH results, the complexes were found to be unresponsive towards MCF7 cells as compared to the untreated control, as well as doxorubicin. (Figure S8). In contrast, a similar activity trend was observed in HKESC-1 with increased ATP in complex + urea + doxorubicin groups (Figure S9).

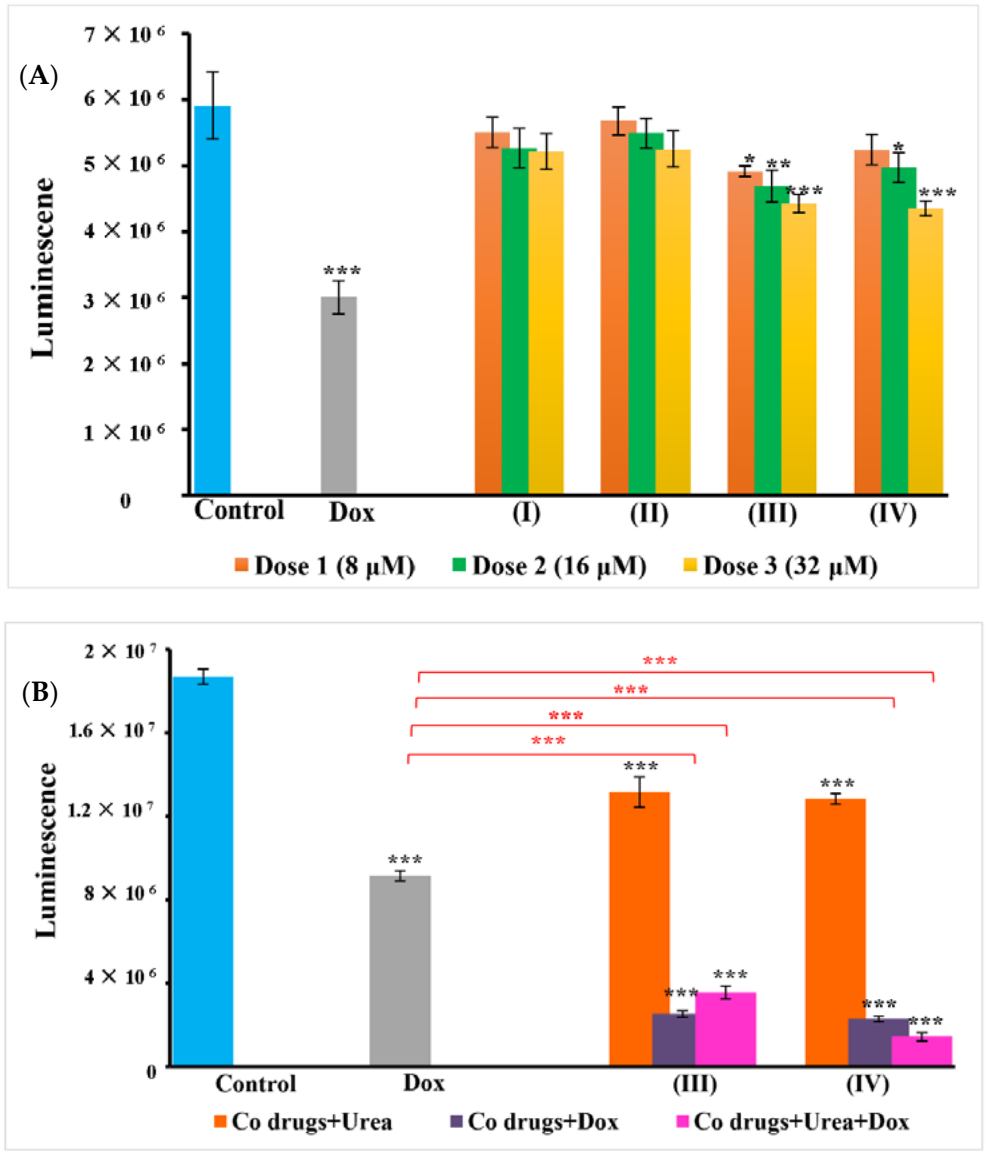

Figure 4. ATP metabolism in A549 cells. (A) The cellular metabolism was accessed with the ATP levels in the control (untreated) and cells treated with different concentrations $(8 \mu \mathrm{M}, 16 \mu \mathrm{M}$, and $32 \mu \mathrm{M})$ of the cobalt complexes. (B) Standardized doses of complex $(32 \mu \mathrm{M})$ combination with urea $(2 \mathrm{mM})$ and doxorubicin $(50 \mathrm{nM})$. The cytotoxic ability is evident in the figure with decreased levels of ATP in cobalt (III) complexes treated groups. As seen in the figure, complexes combination with urea and doxorubicin profound decrease in ATP. (A,B) clearly depict the difference in the action of cobalt complexes alone and in combination with doxorubicin and urea. Here, the cytotoxic activity and decrease in ATP levels of complexes (III and IV) treated groups signify their ability to boost the action of doxorubicin against A549 cells. The data represent the mean \pm SEM. Results are significantly different at ${ }^{*} p<0.05,{ }^{* *} p<0.01$ and ${ }^{* *} p<0.001$ when compared to control and doxorubicin. 


\subsection{Cellular Morphology}

The A549 cells which were incubated with the cobalt complexes alone and in combination with urea and doxorubicin for $24 \mathrm{~h}$ showed distinct morphology in a concentration dependent manner compared to the control. The cells showed signs of cell death, with deformed membrane integrity, losing inter-cellular contact, vacuolation, rounding of cells and detachment from the culture plates (Figure 5). The toxicity of complexes on HKESC-1 cells was evident in morphology images (Figure S11); however, unlike A549, MCF7 cells did not respond well to the treatment (Figure S10).
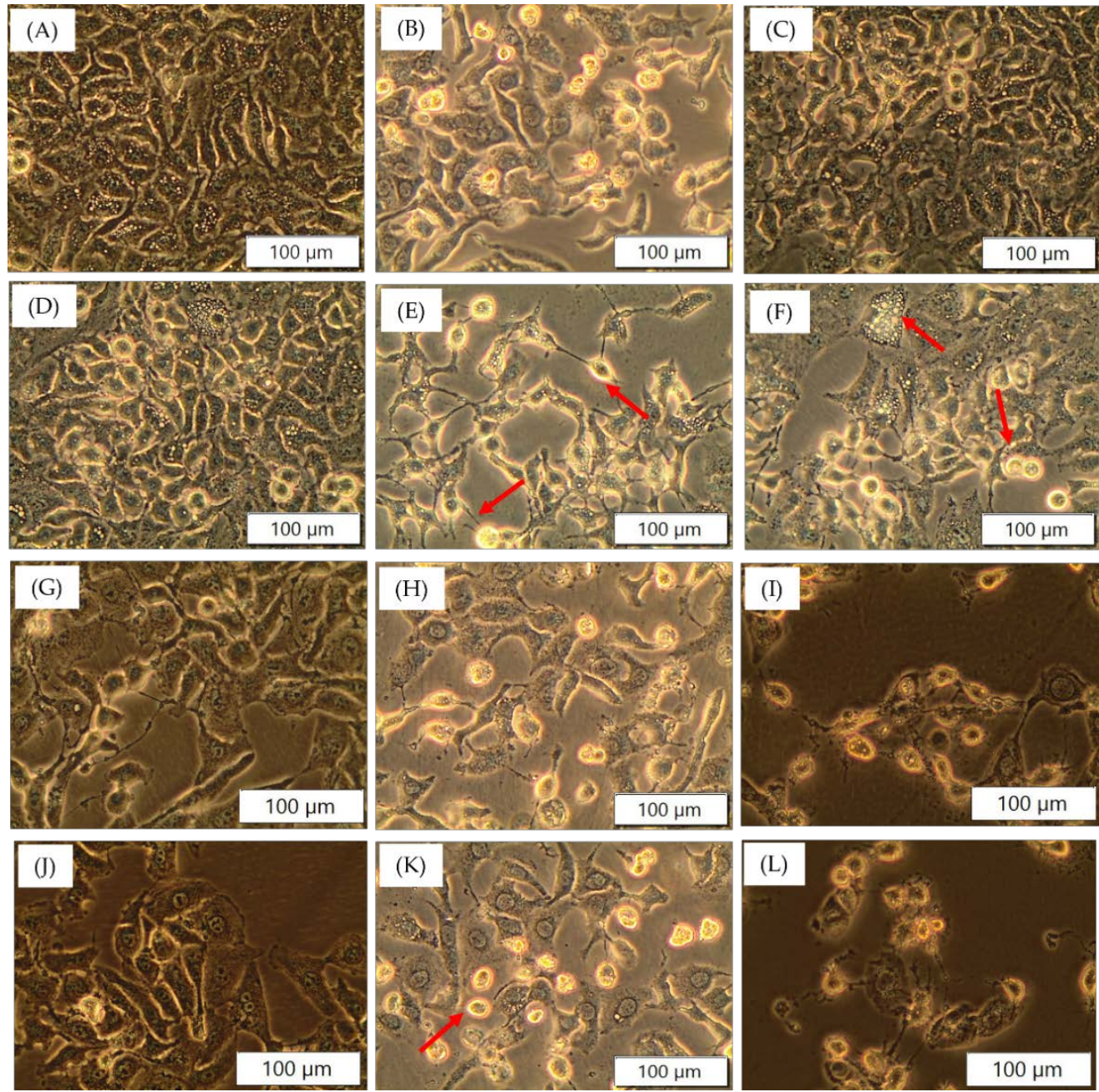

Figure 5. Morphology of A549 treated with cobalt complexes, urea and doxorubicin. (A) Control (untreated); (B) Dox (50 nM); (C) $32 \mu \mathrm{M}$ (I); (D) $32 \mu \mathrm{M}$ (II) (E) $32 \mu \mathrm{M}$ (III); (F) $32 \mu \mathrm{M}$ (IV); (G) $32 \mu \mathrm{M}$ (III) +2 mM urea; (H) $32 \mu \mathrm{M}$ (III) + 50 nM Dox; (I) $32 \mu \mathrm{M}$ (III) + 2 mM urea + 50 nM Dox; (J) $32 \mu \mathrm{M}$ (IV) +2 mM urea; (K) $32 \mu \mathrm{M}$ (IV) + $50 \mathrm{nM}$ Dox; (L) $32 \mu \mathrm{M}$ (IV) + 2 mM urea + $50 \mathrm{nM}$ Dox. Intact cellular morphology is seen in the control group compared to treated groups. Clear and evident round cells detached from culture plate (indicated with arrows) can be seen in the image. Vacuole formation (arrow in (D)), shrinkage of cells, fewer cell population indicates low cell proliferation and increased cell death. These signs of cell death are more prominent in group $(\mathbf{I}, \mathbf{L})$ where the complexes in presence of urea might have facilitated cytotoxic action of doxorubicin.

\subsection{Trypan Blue Viability Assay}

As observed in LDH and ATP assays, cell viability significantly reduced in A549 cells on treatment with the cobalt complexes and the urea and doxorubicin combinations (Figure 6). The cells were quantified as dead with their ability to take up trypan blue dye due to membrane disruption and permeability. The maximum number of dead cells was 
observed in complex combination with urea and doxorubicin compared to other treatment groups. It was interesting to note that all the assay results complemented each other, signifying the importance of drug combination and the role of cobalt (III) complexes in modifying cancer cell microenvironment in enhancing cell death.
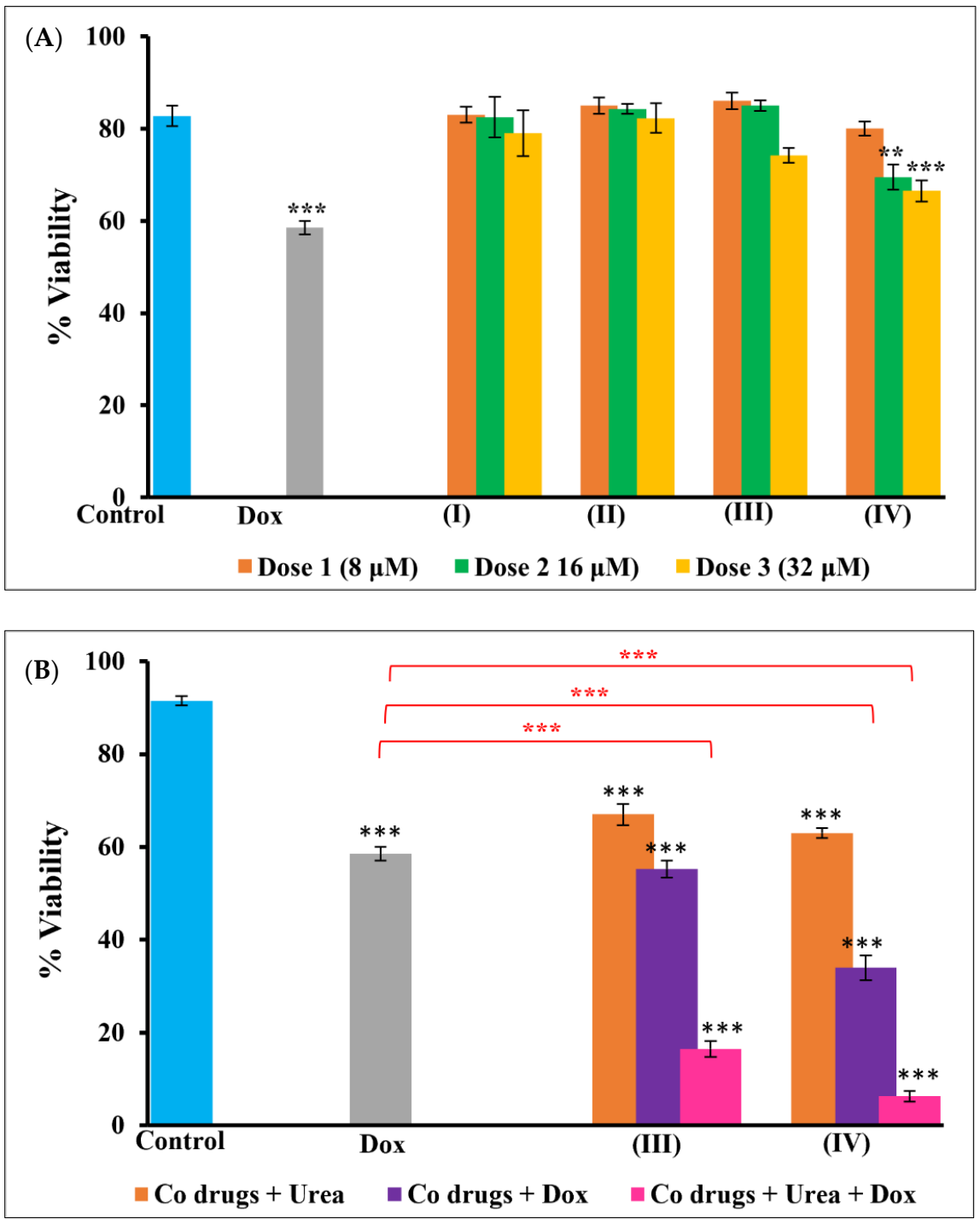

Figure 6. Trypan blue viability test in A549 cells. Graph (A) shows the viability of A549 cells treated with complex alone and in combination with doxorubicin. Graph (B) shows the commendable increase in the ability of doxorubicin in inducing cell death when combined with urea. As seen in other assays, cobalt III and IV complexes induced better toxicity in A549 cells compared to other complexes as seen in (A). Moreover, urea and doxorubicin induced more cell death whereby these cells stained well with trypan blue. Significance in these groups can be seen increased by several folds. Results are significantly different at ${ }^{* *} p<0.01$ and ${ }^{* * *} p<0.001$ when compared to control and doxorubicin.

\subsection{Caspase $3 / 7$ Activity}

Caspase $3 / 7$ is one of the important executioner cascades leading to apoptosis. The results can be promptly seen in cobalt complexes (III and IV) in combination with urea and doxorubicin. The luminescent signals elevated in these groups compared to control and authenticate the role of caspases in inducing cell death (Figure 7). 


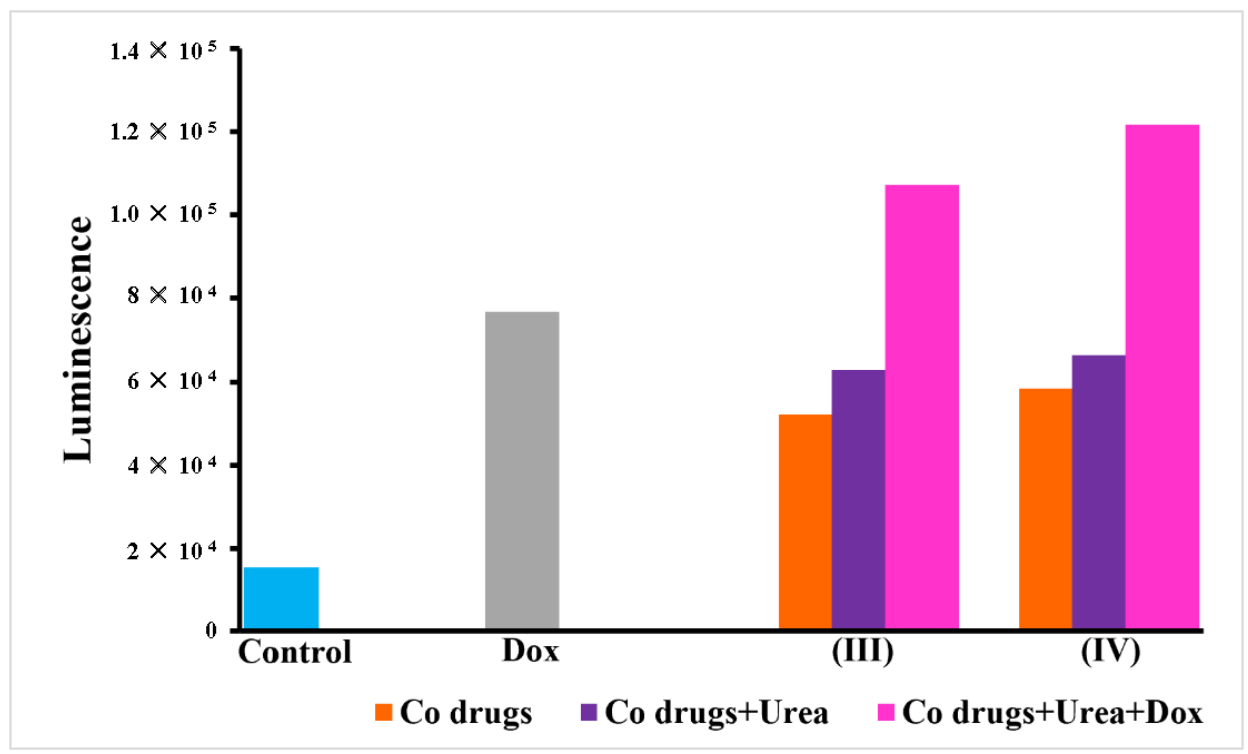

Figure 7. Caspase $3 / 7$ activity in treated A549 cells. The figure shows comparative caspases activity in A549 cells treated with doxorubicin alone and in combination with cobalt complexes and urea. An increase in luminescence and thus enhanced caspase 3/7 activity is clear in the combination group.

\section{Discussion}

Currently, cancer research is dominated by the need and design of target specific anticancer drugs with minimal side effects. One way to achieve this is to alter the tumour microenvironment. The acidic tumour microenvironment plays a pivotal role in the growth and sustenance of tumour cells by inducing resistance and T-cell stasis, thereby assisting the tumour to evade the self-immune mechanism [20,51]. The acidity in the microenvironment also results in the localization of basic drugs in the extracellular matrix, thereby reducing the effective drug dosage. This often results in poor activity and drug resistance [20]. In the present study, we have explored an approach for indirectly altering the tumour microenvironment by urease mimetic cobalt (III) complexes. We have presented the preliminary results of the cytotoxicity of urease mimetic cobalt (III) complexes alone, and in combination with a weakly basic drug, doxorubicin. The complexes, on their own exhibit weak cytotoxicity towards A549 cells. This activity is enhanced by many folds by introducing $2 \mathrm{mM}$ urea to the cell culture medium. The concentration of urea used in the present study was decided based on literature reports. The cytotoxicity of urea towards A549 cells was reported by Wong et al. to be $13 \mathrm{mM}$ in the presence on $2 \mathrm{U} / \mathrm{mL}$ of urease. Urea alone was shown to be non-toxic up to $40 \mathrm{mM}$ concentrations [19]. Therefore, the present work was performed by introducing a very low concentration of urea in the cell culture medium which itself has shown a significant role in promoting cell death of A549 cells in this study. The cobalt (III) complexes hydrolyse urea generating ammonia and bicarbonate, and consequently raising the $\mathrm{pH}$ in the surrounding microenvironment. The urease mimetic activity of the cobalt complexes was measured extracellularly in the cell culture medium. The efficacy of the cobalt drugs was also tested against MCF7; however, unpredictably, the observed cytotoxicity was poor against MCF7, as compared to that observed against A549. The selective activation of the complexes in the presence of A549, but not MCF7 was quite intriguing. Initially, we postulated that the culture media used for the growth and maintenance of the cells play a role in the activity of the complexes since all other parameters were constant during the studies. A549 cells were grown in RPMI base media and MCF7 cells were grown in DMEM. Possibly, the cobalt complexes interact with the constituents of the culture media and are rendered inactive or inert in DMEM, which results in loss of catalytic and anticancer activity in vitro. To further understand the role of cell culture media in the observed anticancer activity, and to rule out the cell line specificity of 
the proposed cobalt drugs, the cytotoxicity of the complexes was also investigated against HKESC-1 cells grown in complete DMEM media. As reported in Figures S6, S9 and S11, the cobalt drugs displayed excellent cytotoxic activity against the oesophageal cancer cells. Moreover, the proposed combination treatment of the cobalt complexes with doxorubicin surpassed the activity of doxorubicin alone, as also seen in A549. Hence, at this stage, we can refute the role of cell culture media in activation and/or deactivation of the cytotoxic activity of the cobalt complexes; however, the exact mechanism of inactivation towards MCF7 cannot be predicted unambiguously at this stage. The complexes might have a higher dose against MCF7. Nevertheless, these results further substantiate our hypotheses, that the complexes exert their anti-cancer action via urease mimetic activity; however, future studies are warranted in vivo and in clinical models to establish the role of these complexes on different types of cancers.

The trends observed for the urease mimetic activity were also reflected in the anticancer activities. The generated ammonia as well as raised $\mathrm{pH}$ upsurges the cytotoxicity of the cobalt (III) complexes towards cancer cells. Such altering of the microenvironment can also be manipulated to enhance the activity of weakly basic drugs. Under acidic conditions, basic drugs, such as doxorubicin, tend to sequester in the acidic extracellular environment, thus failing to diffuse into the hydrophobic cell membrane. This often results in loss of therapeutic activity and drug resistance. In this study, we report a combination therapy of the cobalt (III) complexes with doxorubicin. The combination is proposed to be working synergistically, wherein the cobalt (III) complexes hydrolyse urea to generate ammonia, thus neutralizing the acidity in the tumour microenvironment. This subsequently, enhances the diffusion of doxorubicin into the cells, thereby, improving the overall cytotoxic activity. The cobalt complexes do not directly target the cancer cells; rather, they act on the extracellular microenvironment, disrupting the physiological factors that enable tumour growth. Thus, they exert a target specific cytotoxic action controlled by the surrounding $\mathrm{pH}$. This can also be attributed to the low toxicity of the complexes towards normal cells that operate under strictly controlled $\mathrm{pH}$ conditions. To further confirm the mechanism of apoptotic action, caspase $3 / 7$ expression was determined in treated groups. Even though the cell death stimulus induced by caspase 3 and 7 differs, they are yet considered universal executioner caspases [52-54]. Activation of these caspases leads to cell shrinkage, chromatin condensation, formation of apoptotic bodies of which a few significant signs can be seen in morphology images of A549. Unlike normal cells, metabolic pathways in cancer tissues are different and play a crucial role in maintaining their uncontrolled growth and proliferation. Mitochondria, being the key regulator of metabolic activities and cell cycle, has emerged as one of the important targets for targeting cancer tissues for improved therapy [55]. Studies focusing on oxygen consumption rate (OCR) and extracellular acidification rate (ECAR) are also known to contribute to cellular $\mathrm{pH}$ through mitochondrial glycolysis and respiration [56]. Similarly, Reactive Oxygen Species (ROS) have been well studied in regulating cell death in cancer. Mitochondria, as the major site of Iron-dependent peroxidation of lipids, generates excessive ROS leading to ferroptosis, a necrotic cell death pathway [57]. Hence, the role of mitochondria in targeted cancer therapy is emerging as a promising research area that may contribute to significant outcomes in studies with similar interests. The tumour microenvironment has shown to play pivotal roles in maintenance of tumour heterogeneity and subsequent cancer metastasis. Therefore, more research is now being directed against the tumour microenvironment along with the cancer cells. There are many proposed methods of targeting the tumour microenvironment, one of which involves neutralization of the acidosis in the microenvironment to improve the diffusion of chemotherapeutic drugs. Currently, a few combination therapies are being tried clinically, namely, a combination of acetazolamide and radiation therapy for small cell lung cancer treatment. This approach targets the carbonic anhydrase enzyme along with the cancer cells [58]. Other reports involve the combination of the isolated and purified urease enzyme extract with drugs such as doxorubicin $[12,22,39,44,51]$. Herein, we report the first combination of using a basic anticancer drug with synthetic urease mimetic transition metal 
complexes. The results suggest admirable synergism, which can combat drug resistance as well. Nevertheless, these are preliminary results that warrant further investigation into developing effective and nontoxic anticancer therapy.

\section{Conclusions}

Urease activity was long viewed as detrimental, and research was mainly focused on inhibiting the enzyme's activity; however, the undesirable urease activity can be utilized to neutralize the acidity in tumour microenvironments, thereby leading to enhanced therapeutic efficiency. We have presented the preliminary results of the cytotoxicity induced by urease mimetic cobalt (III) complexes on lung cancer cells. The cytotoxicity results correlate well with the observed urease mimetic activity. The complexes reported in this study are found to be nontoxic towards normal cells, making them an ideal drug candidate for treating cancer cells. To further understand the application of these complexes as anticancer drugs, their dose responses on MCF-7 and HKESC-1 were also studied. With moderate toxicity on MCF-7 but commendable action against HKESC-1 cells, it can be concluded that the active complexes (III and IV) were not cell line specific and further research is warranted to understand the reason behind these specificities. Moreover, synthetic enzyme mimics based on transition metal complexes serve several advantages over the actual enzyme; they are robust, with long shelf life, and often can greatly reduce the cost of manufacturing. The urease, like the action of the cobalt (III) complexes, also improves the therapeutic activity of weakly basic drugs, such as doxorubicin, by inducing apoptosis as seen by the expression of caspase3/7 in treated groups; however, the conflicting results obtained with MCF7 cell lines warrant further investigation using in vivo and clinical models. The concept introduced in this article is worthwhile and deserves further investigation.

Supplementary Materials: The following supporting information can be downloaded at: https:/ / www.mdpi.com/article/10.3390/pharmaceutics14010211/s1, Characterization data for all the cobalt complexes. Figure S1: UV/Vis spectra of the cobalt (III) complexes in the cell culture media (RPMI supplemented with 10\% foetal bovine serum, $1 \%$ Penicillin-streptomycin, and 1\% amphotericin-B) displaying the stability of complexes in the cell culture media, Figure S2: Molecular structure of $\left[\mathrm{Co}^{\mathrm{III}}\right.$ (trien) $\left.\mathrm{Cl}_{2}\right] \mathrm{Cl} \cdot \mathrm{H}_{2} \mathrm{O}$ with displacement ellipsoids drawn at $50 \%$ probability, showing the atomic numbering scheme where the heteroatoms have been labelled only for clarity. Dashed red and green lines indicate hydrogen bonds. The crystals were grown by slow evaporation of a solution of [Co(trien) $\left.\mathrm{Cl}_{2}\right] \mathrm{Cl}$ in RPMI supplemented with $10 \%$ foetal bovine serum, $1 \%$ Penicillin-streptomycin, and $1 \%$ amphotericin-B, Figure S3: Molecular structure of $\left[\mathrm{Co}{ }^{\mathrm{III}}(\right.$ tren $\left.)\left(\mathrm{NO}_{2}\right)_{2}\right] \mathrm{Cl}$ with displacement ellipsoids drawn at $50 \%$ probability, showing the atomic numbering scheme where the heteroatoms have been labelled only for clarity. Dashed red and green lines indicate hydrogen bonds. The crystals were grown by slow evaporation of a solution of $\left[\mathrm{Co}(\operatorname{tren})\left(\mathrm{NO}_{2}\right)_{2}\right] \mathrm{Cl}$ in RPMI supplemented with $10 \%$ foetal bovine serum, $1 \%$ Penicillin-streptomycin, and 1\% amphotericin-B, Figure S4: LDH levels of WS1 cells treated with $32 \mu \mathrm{M}$ of each of the cobalt complexes. The results were non-significant at $p<0.05$ compared to control representing the safety of the Co (III) complexes against WS1 cells, Figure S5: LDH levels of MCF7 cells. [Co drugs]: $32 \mu \mathrm{M}$, [urea]: 2mM, [Dox]: $50 \mathrm{nM}$, Figure S6: LDH levels of HKESC-1 cells. [Co drugs]: $32 \mu \mathrm{M}$, [urea]: 2mM, [Dox]: $50 \mathrm{nM}$, Figure S7: ATP metabolism in WS1 cells treated with $32 \mu \mathrm{M}$ of each of the cobalt complexes. The results were non-significant at $p<0.05$ compared to control representing the safety of the Co (III) complexes against WS1 cells, Figure S8: ATP proliferation of MCF7 cells. [Co drugs]: $32 \mu \mathrm{M}$, [urea]: 2mM, [Dox]: $50 \mathrm{nM}$, Figure S9: ATP proliferation of HKESC-1 cells. [Co drugs]: $32 \mu \mathrm{M}$, [urea]: 2mM, [Dox]: $50 \mathrm{nM}$, Figure S10: Morphology of MCF7 treated with cobalt complexes, urea and doxorubicin. (A) Control; (B) Dox (50 nM); (C) $32 \mu \mathrm{M}$ (III); (D) $32 \mu \mathrm{M}$ (IV); (E) $32 \mu \mathrm{M}$ (III) $+2 \mathrm{mM}$ urea; (F) $32 \mu \mathrm{M}$ (IV) + 2 mM urea; (G) $32 \mu \mathrm{M}$ (III) $+2 \mathrm{mM}$ urea + $50 \mathrm{nM}$ Dox; (H) $32 \mu \mathrm{M}$ (IV) +2 mM urea + $50 \mathrm{nM}$ Dox, Figure S11. Morphology of HKESC-1 treated with cobalt complexes, urea and doxorubicin. (A) Control; (B) Dox (50 nM); (C) $32 \mu \mathrm{M}$ (III); (D) $32 \mu \mathrm{M}$ (IV); (E) $32 \mu \mathrm{M}$ (III) + 2mM urea; (F) $32 \mu \mathrm{M}$ (IV) + $2 \mathrm{mM}$ urea; (G) $32 \mu \mathrm{M}$ (III) $+2 \mathrm{mM}$ urea $+50 \mathrm{nM}$ Dox; (H) $32 \mu \mathrm{M}$ (IV) $+2 \mathrm{mM}$ urea $+50 \mathrm{nM}$ Dox. 


\begin{abstract}
Author Contributions: Conceptualization, B.U. and R.C.; writing-original draft preparation, B.U. and R.C.; writing - review and editing, B.U., R.C., C.A. and H.A.; supervision, C.A. and H.A.; funding acquisition, H.A. All authors have read and agreed to the published version of the manuscript.

Funding: This work is based on the research supported by the South African Research Chairs Initiative of the Department of Science and Technology and National Research Foundation of South Africa (Grant No 98337), as well as grants received from the University of Johannesburg (URC), the National Research Foundation (NRF), and the CSIR (Council for Scientific and industrial Research)NLC (National Laser Centre) Laser Rental Pool Programme, and the National Research Foundation Thuthuka Program (NRF-Grant No 117946).
\end{abstract}

Institutional Review Board Statement: Not applicable.

Informed Consent Statement: Not applicable.

Data Availability Statement: Not applicable.

Acknowledgments: B.U. is thankful to the Laser Research Centre and H.A. for awarding NRF SARCHi Post Doctoral Fellowship.

Conflicts of Interest: The authors declare no conflict of interest.

\title{
References
}

1. Sritharan, S.; Sivalingam, N. A comprehensive review on time-tested anticancer drug doxorubicin. Life Sci. 2021, $278,119527$. [CrossRef] [PubMed]

2. Simões, R.; Silva, L.M.; De Oliveira, A.N.; Alves, M.T.; Pestana, R.M.C.; De Souza, I.D.P.; Oliveira, H.H.M.; Soares, C.E.; Sabino, A.D.P.; Gomes, K.B. Identification of Clinical and Laboratory Variables Associated with Cardiotoxicity Events Due to Doxorubicin in Breast Cancer Patients: A 1-Year Follow-Up Study. Cardiovasc. Toxicol. 2012, 21, 106-114. [CrossRef]

3. Tripathi, R.; Kumar, A. Application of Nanorobotics for Cancer Treatment. Mater. Today Proc. 2018, 5, 9114-9117. [CrossRef]

4. Hortelão, A.C.; Patiño, T.; Perez-jiménez, A.; Blanco, À.; Sánchez, S. Enzyme-Powered Nanobots Enhance Anticancer Drug Delivery. Adv. Funct. Mater. 2018, 28, 1705086. [CrossRef]

5. Li, Z.; Tan, S.; Li, S.; Shen, Q.; Wang, K. Cancer drug delivery in the nano era: An overview and perspectives (Review). Oncol. Rep. 2017, 38, 611-624. [CrossRef]

6. Liu, Y.; Wang, J.; Xiong, Q.; Hornburg, D.; Tao, W.; Farokhzad, O.C. Nano-Bio Interactions in Cancer: From Therapeutics Delivery to Early Detection. Acc. Chem. Res. 2021, 54, 291-301. [CrossRef] [PubMed]

7. Farkona, S.; Diamandis, E.P.; Blasutig, I.M. Cancer immunotherapy: The beginning of the end of cancer? BMC Med. 2016, 14, 73. [CrossRef] [PubMed]

8. Kirkwood, J.M.; Butterfield, L.H.; Tarhini, A.A.; Zarour, H.; Kalinski, P.; Ferrone, S. Immunotherapy of cancer in 2012. CA Cancer J. Clin. 2012, 62, 309-335. [CrossRef]

9. Cao, R.; Song, W.; Ye, C.; Liu, X.; Li, L.; Li, Y.; Yao, H.; Zhou, X.; Li, L.; Shao, R. Internal enhancement of DNA damage by a novel bispecific antibody-drug conjugate-like therapeutics via blockage of mTOR and PD-L1 signal pathways in pancreatic cancer. Cancer Med. 2019, 8, 643-655. [CrossRef]

10. Thomas, A.; Teicher, B.A.; Hassan, R. Antibody-drug conjugates for cancer therapy. Lancet Oncol. 2016, 17, e254-e262. [CrossRef]

11. Chau, C.H.; Steeg, P.S.; Figg, W.D. Antibody-drug conjugates for cancer. Lancet 2019, 394, 793-804. [CrossRef]

12. Chao, H. DOS47-Killing Cancer by Altering the Tumor Microenvironment. Drug Deliv. Technol. 2011, 11, 68-72.

13. Damgaci, S.; Ibrahim-Hashim, A.; Enriquez-Navas, P.M.; Pilon-Thomas, S.; Guvenis, A.; Gillies, R.J. Hypoxia and acidosis: Immune suppressors and therapeutic targets. Immunology 2018, 154, 354-362. [CrossRef]

14. Wong, W.Y.; Uger, M.D.; Wisniewski, P.; Chao, H.; Tian, B. Development and Characterization of a Camelid Single Domain Antibody-Urease Conjugate That Targets Vascular Endothelial Growth Factor Receptor 2. Front. Immunol. 2017, 8, 1-19. [CrossRef]

15. Albini, A.; Sporn, M.B. The tumour microenvironment as a target for chemoprevention. Nat. Rev. Cancer 2007, 7, 139-147. [CrossRef]

16. Dai, Y.; Xu, C.; Sun, X.; Chen, X. Nanoparticle design strategies for enhanced anticancer therapy by exploiting the tumour microenvironment. Chem. Soc. Rev. 2017, 46, 3830-3852. [CrossRef]

17. Cassim, S.; Pouyssegur, J. Tumor Microenvironment: A Metabolic Player that Shapes the Immune Response. Int. J. Mol. Sci. 2019, 21, 157. [CrossRef]

18. Petrova, V.; Annicchiarico-Petruzzelli, M.; Melino, G.; Amelio, I. The hypoxic tumour microenvironment Hypoxia and hypoxiainducible factors. Oncogenesis 2018, 7, 10. [CrossRef]

19. Wong, W.Y.; DeLuca, C.I.; Tian, B.; Wilson, I.; Molund, S.; Warriar, N.; Govindan, M.V.; Segal, D.; Chao, H. Urease-induced alkalinization of extracellular $\mathrm{pH}$ and its antitumor activity in human breast and lung cancers. J. Exp. Ther. Oncol. 2005, 5, 93-99.

20. Pillai, S.R.; Damaghi, M.; Marunaka, Y.; Spugnini, E.P.; Fais, S.; Gillies, R.J. Causes, consequences, and therapy of tumors acidosis. Cancer Metastasis Rev. 2019, 38, 205-222. [CrossRef] 
21. Wojtkowiak, J.W.; Verduzco, D.; Schramm, K.J.; Gillies, R.J. Drug resistance and cellular adaptation to tumor acidic pH microenvironment. Mol. Pharm. 2011, 8, 2032-2038. [CrossRef]

22. Tian, B.; Wong, W.Y.; Hegmann, E.; Gaspar, K.; Kumar, P.; Chao, H. Production and Characterization of a Camelid Single Domain Antibody-Urease Enzyme Conjugate for the Treatment of Cancer. Bioconjug. Chem. 2015, 26, 1144-1155. [CrossRef]

23. Kafarski, P.; Talma, M. Recent advances in design of new urease inhibitors: A review. J. Adv. Res. 2018, 13, 101-112. [CrossRef]

24. Follmer, C.J. Ureases as a target for the treatment of gastric and urinary infections. J. Clin. Pathol. 2010, 63, 424-430. [CrossRef]

25. Casali, L.; Mazzei, L.; Shemchuk, O.; Honer, K.; Grepioni, F.; Ciurli, S.; Braga, D.; Baltrusaitis, J. Smart urea ionic co-crystals with enhanced urease inhibition activity for improved nitrogen cycle management. Chem. Commun. 2018, 54, 7637-7640. [CrossRef]

26. Musiani, F.; Arnofi, E.; Casadio, R.; Ciurli, S. Structure-based computational study of the catalytic and inhibition mechanisms of urease. J. Biol. Inorg. Chem. 2001, 6, 300-314. [CrossRef]

27. You, Z.L.; Zhang, L.; Shi, D.H.; Wang, X.L.; Li, X.F.; Ma, Y.P. Synthesis, crystal structures and urease inhibitory activity of copper(II) complexes with Schiff bases. Inorg. Chem. Commun. 2010, 13, 996-998. [CrossRef]

28. Nile, S.H.; Keum, Y.S.; Nile, A.S.; Jalde, S.S.; Patel, R.V. Antioxidant, anti-inflammatory, and enzyme inhibitory activity of natural plant flavonoids and their synthesized derivatives. J. Biochem. Mol. Toxicol. 2018, 32. [CrossRef]

29. Xiao, Z.P.; Wang, X.D.; Peng, Z.Y.; Huang, S.; Yang, P.; Li, Q.S.; Zhou, L.H.; Hu, X.J.; Wu, L.J.; Zhou, Y.; et al. Molecular Docking, kinetics study, and structure-activity relationship analysis of quercetin and its analogous as helicobacter pylori urease inhibitors. J. Agric. Food Chem. 2012, 60, 10572-10577. [CrossRef]

30. Habala, L.; Devínsky, F.; Egger, A.E. REVIEW: Metal complexes as urease inhibitors. J. Coord. Chem. 2018, 71, 907-940. [CrossRef]

31. You, Z.-L.; Ni, L.-L.; Shi, D.-H.; Bai, S. Synthesis, structures, and urease inhibitory activities of three copper(II) and zinc(II) complexes with 2-\{[2-(2-hydroxyethylamino)ethylimino]methyl\}-4-nitrophenol. Eur. J. Med. Chem. 2010, 45, 3196-3199. [CrossRef] [PubMed]

32. Zhang, L.; Mulrooney, S.B.; Leung, A.F.K.; Zeng, Y.; Ko, B.B.C.; Hausinger, R.P.; Sun, H. Inhibition of urease by bismuth(III): Implications for the mechanism of action of bismuth drugs. BioMetals 2006, 19, 503-511. [CrossRef] [PubMed]

33. Uprety, B.; Arderne, C.; Bernal, I. Catalytic Cleavage of the Amide Bond in Urea Using a Cobalt(III) Amino-Based Complex. Eur. J. Inorg. Chem. 2018, 2018, 5058-5067. [CrossRef]

34. Saha, M.K.; Mukhopadhyay, U.; Bernal, I. Cleavage of the peptide bond of $\beta$-alanyl-L-histidine(carnosine) induced by a Co III-amine complexes: Reaction, structure and mechanism. Dalt. Trans. 2004, 1466-1473. [CrossRef]

35. Saha, M.K.; Bernal, I. An unprecedented trans-oriented product from the cleavage of a dipeptide. Chem. Commun. 2003, 5, 612-613. [CrossRef]

36. Rajendran, R.; Pandi, A.; Ramchary, A.; Thiagarajan, H.; Panneerselvam, J.; Niraikulam, A.; Kuppuswami, G.M.; Ramudu, K.N. Extracellular urease from Arthrobacter creatinolyticus MTCC 5604: Scale up, purification and its cytotoxic effect thereof. Mol. Biol. Rep. 2018, 46, 133-141. [CrossRef]

37. Chao, H.; Wong, W.Y.; Tian, B.; Gaspar, K.J.; Kumar, P. Antibody-Urease Conjugates for Therapeutic Purposes. U.S. Patent No. 10316311, 28 July 2016.

38. Chao, H. Use of Antibody-Urease Conjugates for Diagnostic and Therapeutic Purposes. International Patent No. WO2014165985A1, 16 October 2014.

39. Rodryg, R.; Dariusz, K.; Cezary, S.; Aleksandra, S.; Elzbieta, W.; Steve, D.; Chao, H.; Roszkowski-Sliz, K. Phase 1 Study of Ramucirumab or Necitumumab in Combination with Osimertinib (AZD9291) in Advanced Topic: Phase I Trials Phase I/II Dose Escalation Study of L-DOS47 as a Monotherapy in Non-Squamous Non-Small Cell Lung Cancer Patients A Phase 1/2 Tri. J. Thoraic Oncol. 2017, 12, 1071-1072. [CrossRef]

40. Cantarella, H.; Otto, R.; Soares, J.R.; de Brito Silva, A.G. Agronomic efficiency of NBPT as a urease inhibitor: A review. J. Adv. Res. 2018, 13, 19-27. [CrossRef] [PubMed]

41. Li, Y.; Hu, M.; Tenuta, M.; Ma, Z.; Gui, D.; Li, X.; Zeng, F.; Gao, X. Agronomic evaluation of polymer-coated urea and urease and nitrification inhibitors for cotton production under drip-fertigation in a dry climate. Sci. Rep. 2020, 10, 1472. [CrossRef]

42. Menteşe, E.; Akyüz, G.; Emirik, M.; Baltaş, N. Synthesis, in vitro urease inhibition and molecular docking studies of some novel quinazolin-4(3H)-one derivatives containing triazole, thiadiazole and thiosemicarbazide functionalities. Bioorg. Chem. 2019, 83, 289-296. [CrossRef]

43. Qu, D.; Niu, F.; Zhao, X.; Yan, K.X.; Ye, Y.T.; Wang, J.; Zhang, M.; You, Z. Synthesis, crystal structures, and urease inhibition of an acetohydroxamate-coordinated oxovanadium(V) complex derived from N???-(3-bromo-2-hydroxybenzylidene)-4methoxybenzohydrazide. Bioorganic Med. Chem. 2015, 23, 1944-1949. [CrossRef]

44. Allawi, M.H.; Abed, M.Q. A Study of Anticancer Activity for Partial Purified Urease Isolated from Lagonychium farctum Plant. Al-Nahrain J. Sci. 2018, 1, 95-99. [CrossRef]

45. Buckingham, D.A.; Cresswell, P.J.; Sargeson, A.M. Site of Deprotonation in the Base Hydrolysis of Chloropentaaminecobalt(III) Ions. Inorg. Chem. 1975, 14, 1485-1490. [CrossRef]

46. Buckingham, D.A.; Collman, J.P. Reaction of Hydroxoaquobis(Ethylenediamine)Cobalt(3) Ion With Amino Acids and Dipeptides and Their Esters and Amides. Inorg. Chem. 1967, 6, 1803-1807. [CrossRef]

47. Guzei, I.A.; Arderne, C. Polymorphism of di-nitro-[tris-(2-amino-eth-yl)amine]-cobalt(III) chloride. Acta Crystallogr. Sect. C Struct. Chem. 2015, 71, 695-700. [CrossRef] [PubMed] 
48. Chen, R.; Shen, Y.; Yang, S.; Zhang, Y. Conformational Design Principles in Total Synthesis. Angew. Chem. Int. Ed. 2020, 59, 14198-14210. [CrossRef]

49. Alastair, G.; Lawson, M.D.; MacCoss, M.; Heer, J.P. Importance of Rigidity in Designing Small Molecule Drugs To Tackle Protein-Protein Interactions (PPIs) through Stabilization of Desired Conformers: Miniperspective. J. Med. Chem. 2017, 61, 4283-4289. [CrossRef]

50. Arderne, C.; Batchelor, K.F.; Uprety, B.; Chandran, R.; Abrahamse, H. Reactivity trends of cobalt(III) complexes towards various amino acids based on the properties of the amino acid alkyl chains. Acta Crystallogr. Sect. C Struct. Chem. 2020, 76, 663-672. [CrossRef] [PubMed]

51. Gillies, R.J.; Pilot, C.; Marunaka, Y.; Fais, S. Targeting acidity in cancer and diabetes. Biochim. Biophys. Acta-Rev. Cancer 2019, 1871, 273-280. [CrossRef] [PubMed]

52. Yamauchi, R.; Sasaki, K.; Yoshida, K. Identification of epigallocatechin-3-gallate in green tea polyphenols as a potent inducer of p53-dependent apoptosis in the human lung cancer cell line A549. Toxicol. In Vitro 2009, 23, 834-839. [CrossRef]

53. Peña, B.; Saha, S.; Barhoumi, R.; Burghardt, R.C.; Dunbar, K.R. Ruthenium(II)-Polypyridyl Compounds with $\pi$-Extended Nitrogen Donor Ligands Induce Apoptosis in Human Lung Adenocarcinoma (A549) Cells by Triggering Caspase-3/7 Pathway. Inorg. Chem. 2018, 57, 12777-12786. [CrossRef] [PubMed]

54. Zhang, C.; Li, C.; Wang, Y.; Xu, L.; He, X.; Zeng, Q.; Zeng, C.; Mai, F.; Hu, B.; Ouyang, D. Chemotherapeutic paclitaxel and cisplatin differentially induce pyroptosis in A549 lung cancer cells via caspase-3/GSDME activation. Apoptosis 2019, 24, 312-325. [CrossRef]

55. D'Souza, G.G.; Wagle, M.A.; Saxena, V.; Shah, A. Approaches for targeting mitochondria in cancer therapy. Biochim. Biophys. Acta 2011, 1807, 689-696. [CrossRef] [PubMed]

56. Plitzko, B.; Loesgen, S. Measurement of Oxygen Consumption Rate (OCR) and Extracellular Acidification Rate (ECAR) in Culture Cells for Assessment of the Energy Metabolism. Bio. Protoc. 2018, 20, 2850. [CrossRef] [PubMed]

57. Vucetic, M.; Daher, B.; Cassim, S.; Meira, W.; Pouyssegur, J. Together we stand, apart we fall: How cell-to-cell contact/interplay provides resistance to ferroptosis. Cell Death Dis. 2020, 11, 789. [CrossRef] [PubMed]

58. Roma-Rodrigues, C.; Mendes, R.; Baptista, P.V.; Fernandes, A.R. Targeting Tumor Microenvironment for Cancer Therapy. Int. J. Mol. Sci. 2019, 20, 840. [CrossRef] [PubMed] 